\title{
Sludge granulation during anaerobic treatment of pre-hydrolysed domestic wastewater
}

\author{
Pablo Ligero and Manuel Soto* \\ Department of Physical Chemistry and Chemical Engineering I, Universidade da Coruña. Campus da Zapateira s/n, \\ 15071 A Coruña, Galiza, Spain
}

\begin{abstract}
The aim of this study was to examine sludge granulation during the anaerobic treatment of pre-hydrolysed municipal wastewater The pretreated wastewater had a total chemical oxygen demand (CODt) of $432 \pm 20 \mathrm{mg} / \mathrm{l}$, a soluble COD (CODs) of $259 \pm 8$ $\mathrm{mg} / \mathrm{l}$, volatile fatty acids (VFA) of $101 \pm 9 \mathrm{mg} / \mathrm{l}$ and suspended solids (SS) of $94 \pm 12 \mathrm{mg} / \mathrm{l}$. Prior to entering the digester, the influent was supplemented with sucrose, which increased the total and soluble COD by $300 \mathrm{mg} / \mathrm{l}$. An upflow anaerobic sludge bed (UASB) digester was operated at different hydraulic retention times (HRT) ranging from $26.7 \mathrm{~h}$ to $2.2 \mathrm{~h}$, while the organic load rate (OLR) ranged from 0.9 to $7.3 \mathrm{kgCOD} / \mathrm{m}^{3} \cdot \mathrm{d}$. Sludge granulation was observed after day 150 of operation, at an $\mathrm{HRT}$ of $3.4 \mathrm{~h}$, when small granules of less than $2 \mathrm{~mm}$ in size appeared. The granules had a weak structure and low density, with the specific methanogenic activity of the sludge being about $0.24 \mathrm{~g} \mathrm{CH}-\mathrm{COD} / \mathrm{gVSS} \cdot \mathrm{d}$. After granulation, the digester performance was $57 \% \mathrm{CODt}$ removal and $76 \%$ CODs removal for steady state operation at an HRT of $3.4 \mathrm{~h}$ and an OLR of $5.6 \mathrm{kgCOD} / \mathrm{m}^{3} \cdot \mathrm{d}$.
\end{abstract}

\section{Nomenclature}

COD:

HRT:

OLR:

SS:

VSS:

VFA:

$\mathrm{CH}_{4}-\mathrm{COD}$ : Methane expressed as COD

UASB: Upflow anaerobic sludge bed (anaerobic digester)

HUSB: Hydrolytic upflow sludge bed (anaerobic digester)

$\mathrm{rCH}_{4}: \quad$ Methane production rate

\section{Introduction}

Anaerobic digestion has become the most commonly used method for the treatment of medium- and high-strength effluents, due to the economy of the process and the low generation of surplus sludge. Different anaerobic technologies have been applied for the treatment of less concentrated effluents, such as domestic wastewater and some industrial effluents, providing good treatment efficiencies at low hydraulic retention times (Hickey et al., 1995). One of the digester designs used for anaerobic digestion is the UASB digester, because it achieves the best results in developing and maintaining a granular sludge.

Most of the studies concentrating on clarifying the granulation process were carried out with medium to high substrate concentrations and at mesophilic $\left(30^{\circ} \mathrm{C}\right.$ to $\left.38^{\circ} \mathrm{C}\right)$ or thermophilic temperatures (Hulshoff Pol, 1989; Fang et al., 1994; Quarmby and Forster, 1995). Furthermore, treatment studies at ambient temperatures were carried out by using granular sludge as an inoculum, since there is a lack of available information on granulation in digesters treating diluted wastewater at ambient temperatures (Soto et al., 1997).

\footnotetext{
* To whom all correspondence should be addressed.

II 34-81-167000; fax: 34-81-167065; e-mail: sotoc@udc.es Received 24 July 2002; accepted in revised form 30 May 2002.
}

Some low-strength wastewaters like domestic and municipal effluents contain significant amounts of both fats and SS, but complex carbohydrates and VFA are among the main organic constituents (Elefsiniotis and Oldham, 1994). Several factors, such as sludge flotation and inhibition due to the effect of fats and longchain fatty acids, or the adsorption of finely dispersed colloidal matter on the surface of the sludge, may cause the granulation process to be difficult or the granular sludge to deteriorate (Sayed, 1987; Rinzema, 1988; Hawkes, 1995). In addition, low gradients of substrate concentration and reduced methanogenic activity at low temperatures could enhance the negative effects of these factors.

Given the contradictory results reported on the feasibility of sludge granulation treating these low-strength municipal wastewaters (Van der Last and Lettinga, 1992; Lettinga et al, 1993; Vieira et al., 1994; Ruiz et al., 1998), several granulation studies have been planned to be included as a part of a more extensive research project dealing with the anaerobic treatment of lowstrength municipal wastewaters. A previous study by Soto et al (1997) reported the influence of temperature on the granulation process during the start-up of UASB digesters treating a dilute synthetic wastewater (500 $\mathrm{mgCOD} / \mathrm{l}$ as sucrose) at mesophilic $\left(30^{\circ} \mathrm{C}\right)$ and psychrophilic $\left(20^{\circ} \mathrm{C}\right)$ temperatures. The results showed that the granulation process followed a similar pattern at both temperatures and complete granulation was achieved between 1 and 2 months after the start-up.

In this paper the results obtained during the start-up and granulation process in a laboratory-scale UASB digester treating a pre-hydrolysed domestic wastewater at ambient temperature $\left(20^{\circ} \mathrm{C}\right)$ supplemented with sucrose as a COD source (300 $\mathrm{mg} \mathrm{COD/l})$ in order to enhance granulation are reported.

\section{Materials and methods}

\section{Anaerobic digester set-up and operation}

The UASB digester was made of Plexiglas and had an active volume of $485 \mathrm{ml}$ with an internal diameter of $35 \mathrm{~mm}$, and a height of $420 \mathrm{~mm}$. The digester was placed in a temperature-regulated 


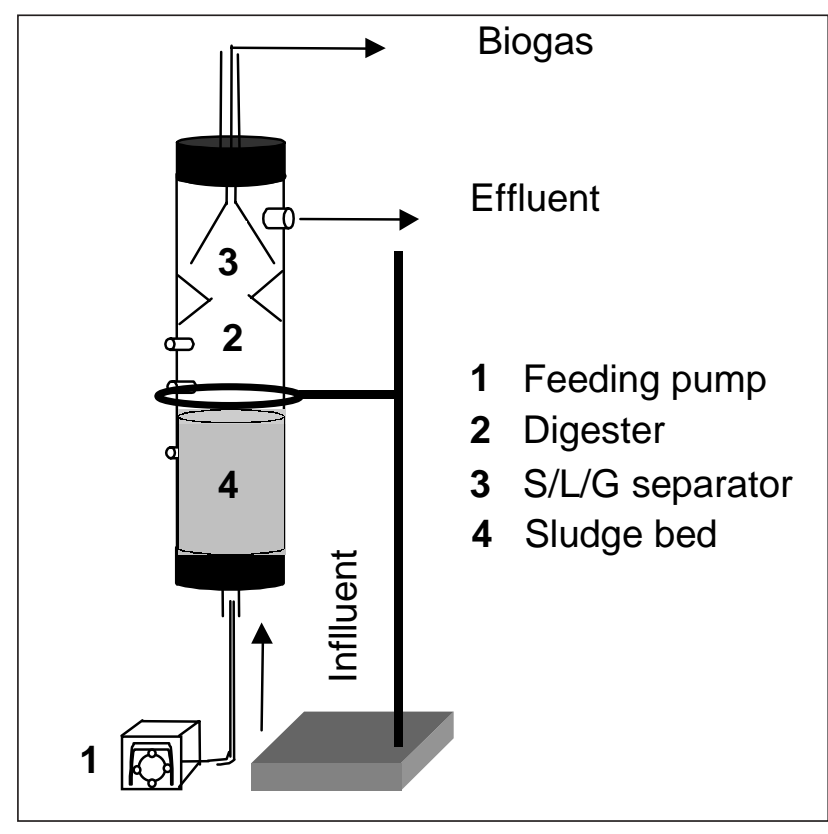

Figure 1

Schematic representation of the digester utilised

TABLE 1

Characteristics of raw and pre-hydrolysed domestic wastewater and UASB digester influent

\begin{tabular}{|c|c|c|c|}
\hline & Raw & $\begin{array}{c}\text { Pre- } \\
\text { hydrolysed }\end{array}$ & $\begin{array}{l}\text { UASB } \\
\text { influent }\end{array}$ \\
\hline $\mathrm{pH}$ & $8.3 \pm 0.2$ & $7.3 \pm 0.1$ & $7.0 \pm 0.00$ \\
\hline CODt & $645 \pm 27$ & $432 \pm 20$ & $732 * \pm 20$ \\
\hline CODs & $302 \pm 13$ & $259 \pm 8$ & $559^{*} \pm 8$ \\
\hline SS & $239 \pm 11$ & $94 \pm 12$ & $94 \pm 12$ \\
\hline VSS & $197 \pm 10$ & $84 \pm 8$ & $84 \pm 8$ \\
\hline $\mathrm{VFA}_{\mathrm{COD}}$ & $21 \pm 2$ & $101 \pm 9$ & $101 \pm 9$ \\
\hline TKN & $91 \pm 11$ & $100 \pm 23$ & $100 \pm 23$ \\
\hline $\mathrm{N}-\mathrm{NH}_{3}$ & $51 \pm 14$ & $83 \pm 31$ & $83 \pm 31$ \\
\hline $\mathrm{P}_{-}-\mathrm{PO}_{4}^{\frac{3}{3-}}$ & $7.5 \pm 1$ & $7.6 \pm 0.8$ & $7.6 \pm 0.8$ \\
\hline $\mathrm{SO}_{4}^{2-{ }^{-4}}$ & $77 \pm 10$ & $67 \pm 5$ & $67 \pm 5$ \\
\hline Alkalinity & $0.26 \pm 0.1$ & $0.33 \pm 0.1$ & $0.33 \pm 0.1$ \\
\hline Fats & $78 \pm 9$ & $32 \pm 11$ & $32 \pm 11$ \\
\hline
\end{tabular}

Concentrations in $\mathrm{mg} / \mathrm{l}$, except $\mathrm{pH}$. Alkalinity is expressed as $\mathrm{mg} \mathrm{CaCO}_{3} / \mathrm{l}$ and VFA as $\mathrm{mg} \mathrm{COD} / \mathrm{l}$. (*) Pre-hydrolysed $+300 \mathrm{mg} / \mathrm{l}$. sucrose.

chamber and operated at $20^{\circ} \mathrm{C}$. In the upper zone there was a solid/ liquid/gas separator. The biogas was channelled to a continuous laboratory-scale gas flow meter as described in Ligero et al. (2001). The digester configuration is shown in Fig. 1.

The digester was seeded with $256 \mathrm{ml}$ of anaerobic stabilised primary sludge. The seed sludge had a concentration of $28.3 \mathrm{~g}$ $\mathrm{SS} / \mathrm{l}$ and $14.9 \mathrm{~g} \mathrm{VSS} / \mathrm{l}$, with a methanogenic activity of $0.046 \mathrm{~g} \mathrm{CH}_{4}$ $\mathrm{COD} / \mathrm{g}$ VSS.d during the first feeding and $0.096 \mathrm{~g} \mathrm{CH}_{4}-\mathrm{COD} / \mathrm{g}$ VSS. $d$ during the second feeding, both at $20^{\circ} \mathrm{C}$, as was obtained from batch assays.

\section{Wastewater feed}

Raw domestic wastewater was pretreated in an HUSB digester as described in Ligero et al. (2001). The characteristics of the HUSB influent and effluent are shown in Table 1. Prior to entering the UASB digester, the pre-hydrolysed domestic wastewater was supplemented with sucrose $(300 \mathrm{mg} C \mathrm{CD} / \mathrm{l})$ and sodium bicarbonate $(300 \mathrm{mg} / \mathrm{l})$, and the $\mathrm{pH}$ was regulated at $7.0 \pm 0.1$ by adding $\mathrm{HCl}$.

\section{Analytical methods}

The determination of SS, VSS, COD (total), $\mathrm{COD}_{\mathrm{s}}$ (soluble), fats, phosphates and sulphates was carried out according to Standard Methods (1985). Total Kjeldahl nitrogen (TKN) was determined by sample digestion with sulphuric acid and a selenium reagent, after which a Kjeldahl apparatus was used for the distillation and titration of the samples with hydrochloric acid. Ammonia was determined by using an ion-selective electrode. Biogas composition was analysed by means of gas chromatography (HP 5890 series II), using a thermal conductivity detector (Standard Methods, 1985), whereas the VFA content was analysed by gas chromatography (HP 5890 SERIE II), using a flame ionisation detector.

\section{Results}

Figure 2 shows the results of the analyses performed on the reactor effluent, while Fig. 3 presents the corresponding conversions reached, in terms of total and soluble COD removal, SS removal, and the methane generation rate in the gas phase, together with the OLR applied. These parameters are presented in Table 2 as averages for each period. Reactor operation was divided into five periods according to the HRT applied. After seeding the digester, feeding was started at a low OLR in order to allow the sludge to become acclimated to the substrate and the operational conditions. The OLR was increased step by step and the digester was operated according to Soto et al. (1997).

During Period I the digester was operated at an HRT of $26.7 \mathrm{~h}$, showing total and soluble COD removal efficiencies of about $80 \%$. The SS removal increased gradually up to $80 \%$, reaching effluent concentrations of about $30 \mathrm{mg} \mathrm{SS} / \mathrm{l}$.

From day 24 to 99 the digester was operated at an HRT of 10.5 to $12.1 \mathrm{~h}$ (Period II). After the HRT decreased on day 24, the removal efficiencies dropped sharply, and recovered only after day 50 of operation. The effluent VFA concentration rose up to 130 $\mathrm{mgCOD} / \mathrm{l}$, indicating that the methanogenic capacity of the digester was too low to accommodate the influent OLR. On other hand, the SS concentration in the effluent increased from 30 to about 100 $\mathrm{mg} / \mathrm{l}$, which was higher than the influent SS concentration. This would mean that part of the inoculated sludge was lost with the effluent.

However, the sludge balance between days 24 and 54 would indicate that the total SS going out into the effluent during this period was only about $28 \%$ of the inoculated SS. Thus, the operational conditions were maintained until the digester efficiency was recovered and stabilised, in terms of gas production and COD removal, as seen in Period IIb. From day 50 to 75 of operation, the methane production progressively increased, while the effluent VFA and SS concentrations decreased, causing the COD removal in Period IIb to be improved.

During Period III the digester was operated at an HRT of $6.1 \mathrm{~h}$, reaching an average OLR of $2.8 \mathrm{kgCOD} / \mathrm{m}^{3} \cdot \mathrm{d}$. The digester maintained the COD removal efficiency (67\%), while the methane production rate increased slightly and the effluent VFA concentration 

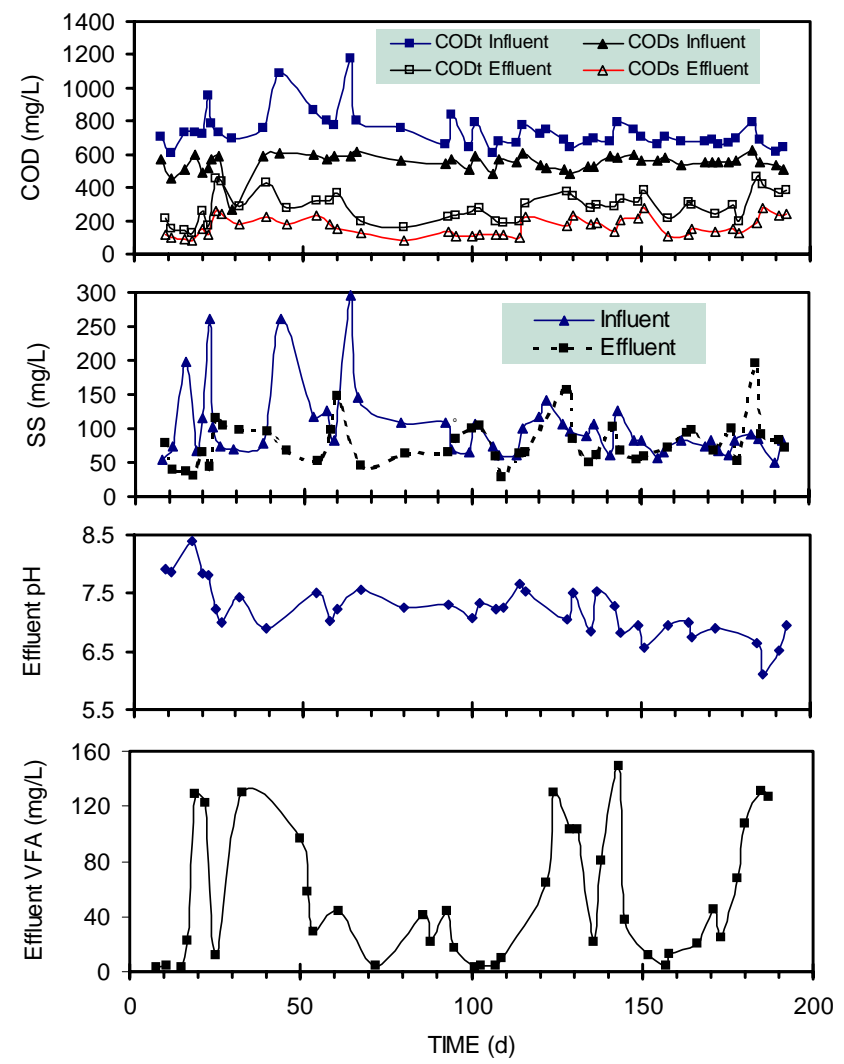

Figure 2

Operational characteristics of the UASB digester

remained low. Furthermore, the operation at this new HRT had no significant effect on the SS lost with the effluent.

On day 114 of operation the HRT was reduced to $3.5 \mathrm{~h}$, and the digester was maintained in this situation until day 170 (Period IV). The OLR increased from 2.8 to $5.3 \mathrm{~kg} \mathrm{COD} / \mathrm{m}^{3} \cdot \mathrm{d}$. The digester showed an increase in effluent COD and VFA concentrations, with a decrease in the COD removal efficiency, but less than what occurred in Period IIa. The effluent SS concentration increased only momentarily (day 125 of operation), and the digester maintained the biomass retention capability.

Between days 150 to 160 of operation the digester efficiency improved, and was later maintained during Period IVb. Low effluent VFA concentrations were recorded, while the methane production rose sharply. Under these operational conditions with an HRT of $3.4 \mathrm{~h}$ and an OLR of $5.6 \mathrm{kgCOD} / \mathrm{m}^{3} \cdot \mathrm{d}$, the digester performance was 57\% CODt removal and $76 \%$ CODs removal. At this time, the presence of a mainly granular sludge in the digester was observed.

A further decrease in the HRT to $2.2 \mathrm{~h}$ was applied on day 171 of operation. Under these conditions there was an increase in sludge washout, leading to an increase in the VFA effluent concentration and a gradual decrease in the methane production rate. By subtracting the influent VSS concentration from the effluent VSS concentration (see average values in Table 2) and taking into account the flow through the system, the minimum amount of biomass washed out during Period V was calculated as $2.7 \mathrm{~g}$ VSS, which was more than twice the amount of VSS in the digester at the end of the operation (see data in next paragraph). Thus, it is clear that a biomass washout occurred during Period V.

The operation was halted on day 193 in order to determine the amount and type of sludge remaining in the digester. At this time,
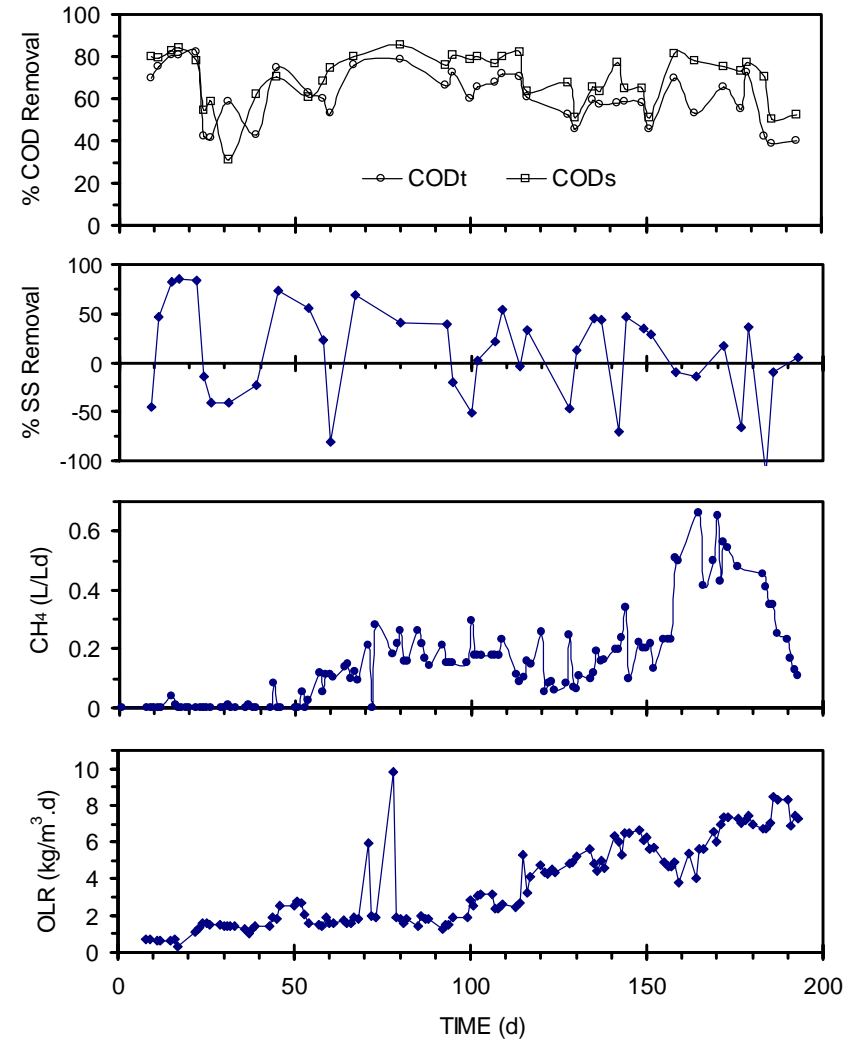

Figure 3

Performance of the UASB digester

the digester had a sludge bed volume of $156 \mathrm{ml}$, with an average of $8.9 \mathrm{gSS} / \mathrm{l}$ and $6.8 \mathrm{gVSS} / \mathrm{l}$. Thus, the amount of sludge in the digester was $1.4 \mathrm{~g} \mathrm{SS}$ and $1.1 \mathrm{~g}$ VSS. This sludge maintained the granular appearance observed after day 150 of operation, presenting granules of less than $2 \mathrm{~mm}$ in size. During sludge handling, part of the granules were destroyed, which is an indication of their weak structure. The specific methanogenic activity of the sludge may be calculated from the rate of methane production and the sludge concentration in the digester, both measured at the end of Period V. A specific methanogenic activity of $0.24 \mathrm{~g} \mathrm{CH}_{4}-\mathrm{COD} / \mathrm{gVSS} \cdot \mathrm{d}$ was calculated.

\section{Discussion and conclusions}

During the treatment of effluents composed mainly of carbohydrates in the mesophilic range of temperatures $\left(35^{\circ} \mathrm{C}\right)$, the granulation process appears to develop slowly as the influent COD concentration decreases to below $500 \mathrm{mg}$ COD/l (Ramos et al., 1994). Other researchers reported that granulation did not occur during the startup of UASB digesters treating a synthetic wastewater composed mainly of glucose (Brito et al., 1997), or during the treatment of a glucose-supplemented domestic sewage (Gnanadiphathy and Polprasert, 1993).

However, in a previous paper it was reported that the granulation process was correctly developed during the start-up of UASB digesters treating a dilute $(500 \mathrm{mg} \mathrm{COD} / \mathrm{L})$ sucrose-based influent (Soto et al., 1997). Complete granulation was achieved between 1 and 2 months after the start-up, at upflow superficial liquid velocities of 0.05 to $0.15 \mathrm{~m} / \mathrm{h}$ and hydraulic retention times (HRT) of 6 to $3 \mathrm{~h}$. 
Operation and conversion characteristics of the UASB digester

\begin{tabular}{|l|c|c|c|c|c|c|c|}
\hline Period & I & Ila & Ilb & III & IVa & IVb & V \\
\hline Days & $1-23$ & $23-50$ & $51-99$ & $99-114$ & $114-158$ & $158-170$ & $170-193$ \\
HRT (h) & 26.73 & 12.09 & 10.48 & 6.11 & 3.45 & 3.40 & 2.21 \\
OLR (kgCOD/m 3 .d) & 0.90 & 1.56 & 2.19 & 2.64 & 5.14 & 5.55 & 7.35 \\
\hline Influent & & & & & & & \\
pH & 7.0 & 7.0 & 7.0 & 7.0 & 7.0 & 7.0 & 7.0 \\
CODt (mg/l) & 748 & 818 & 813 & 688 & 710 & 678 & 681 \\
CODs (mg/l) & 531 & 512 & 572 & 549 & 551 & 545 & 555 \\
SS (mg/l) & 125 & 121 & 124 & 75 & 95 & 78 & 75 \\
VSS (mg/l) & 105 & 105 & 109 & 68 & 86 & 71 & 66 \\
VFA (mgCOD/l) & 82 & 86 & 114 & 100 & 120 & 115 & 93 \\
\%AcH & 93 & 85 & 88 & 83 & 88 & 89 & 87 \\
\hline Effluent & & & & & & & \\
pH & 7.08 & 7.13 & 7.31 & 7.31 & 7.10 & 6.88 & 6.62 \\
CODt (mg/l) & 169 & 377 & 258 & 223 & 313 & 304 & 338 \\
CODs (mg/l) & 106 & 218 & 145 & 111 & 193 & 133 & 193 \\
SS (mg/l) & 43 & 96 & 80 & 70 & 77 & 96 & 95 \\
VSS (mg/l) & 39 & 80 & 66 & 64 & 70 & 90 & 88 \\
VFA (mgCOD/l) & 8 & 98 & 42 & 15 & 71 & 8 & 75 \\
\%AcH & 87 & 67 & 75 & 77 & 55 & 69 & 66 \\
\hline Conversion & & & & & & & \\
r CH4 (I/l·d) & 0.003 & 0.006 & 0.14 & 0.18 & 0.17 & 0.54 & 0.34 \\
\%CODt & 78 & 52 & 67 & 67 & 56 & 57 & 51 \\
\%CODs & 81 & 55 & 75 & 79 & 65 & 76 & 65 \\
\%SS & 50 & -9 & 18 & 4 & 12 & -15 & -22 \\
\%VSS & 52 & -3 & 25 & -3 & 13 & -19 & -30 \\
\hline
\end{tabular}

Regarding the influence of temperature, the results indicated that the granulation process followed a similar pattern at temperatures for both $30^{\circ} \mathrm{C}$ and $20^{\circ} \mathrm{C}$. At $20^{\circ} \mathrm{C}$, the UASB system showed excellent stability and high treatment efficiency which were maintained even when the OLR was increased to up to $9 \mathrm{~kg} \mathrm{COD} /$ $\mathrm{m}^{3} \cdot \mathrm{d}$, at an HRT of $1.3 \mathrm{~h}$.

Anaerobic treatment of domestic and other diluted effluents should be carried out at ambient temperatures, normally in the psycrophilic range, from $10^{\circ} \mathrm{C}$ to $26^{\circ} \mathrm{C}$, depending on the season and place.

There have been contradictory results on the feasibility of sludge granulation treating this low-strength municipal wastewater. The results of the majority of the studies on domestic wastewater treatment in UASB digesters indicate that these systems operate with low activity flocculent sludge at ambient or psychrophilic temperatures (Lettinga et al., 1993; Ruiz et al., 1998). Some authors (Vieira et al, 1994; Van der Last and Lettinga, 1992) reported the granulation of the seed sludge during the treatment of pre-settled domestic sewage. The granular sludge was not negatively affected when the influent was changed to raw sewage (Vieira et al., 1994). However, Elmitwalli et al. (1999) reported that during the treatment of raw domestic wastewater in a digester inoculated with granular sludge, the suspended and colloidal solids contained in the wastewater caused the flotation and deterioration of the sludge. Singh et al. (1996) carried out the start-up of a pilot UASB (4 m in height) treating a dilute (300 to $500 \mathrm{mg} \mathrm{COD} / \mathrm{l}$ ) wastewater at temperatures from 25 to $30^{\circ} \mathrm{C}$. The synthetic substrate was composed of cellulose, as suspended solids (100 mg SS/l), sucrose (350 mg/ I) and peptone $(50 \mathrm{mg} / \mathrm{l})$. The OLR ranged from 1 to $4 \mathrm{~kg} \mathrm{COD} / \mathrm{m}^{3} \cdot \mathrm{d}$ and the HRT from 3 to $6 \mathrm{~h}$. Under these conditions the sludge became granular, but with poor sedimentation characteristics, as the biomass retention capability of the digester was low at an HRT of $3 \mathrm{~h}$ and an upflow velocity of $1.3 \mathrm{~m} / \mathrm{h}$.

In this study, the influent to the UASB digester was a prehydrolysed domestic wastewater supplemented with sucrose, having an SS concentration of less than $100 \mathrm{mg} / \mathrm{l}$. The nature and concentration of the biodegradable substrate were similar to those described in Soto et al. (1997), using only sucrose as the carbon source. Thus, the differences found in relation to the granulation process could be attributed to the effect of both suspended or colloidal solids, or to the influence of other wastewater characteristics, but not to the type of biodegradable carbon source, COD concentration or temperature.

These results indicate that granulation during the start-up of a UASB digester treating this pre-hydrolysed, sucrose-supplemented, domestic wastewater developed more slowly than during the treatment of a sucrose-based synthetic effluent. Granular sludge was not observed until $150 \mathrm{~d}$ after the start-up, in comparison with only $60 \mathrm{~d}$ in the digester treating synthetic effluent. Furthermore, the granules formed were smaller and less resistant, although their methanogenic activity was quite similar $\left(0.25\right.$ to $0.35 \mathrm{~g} \mathrm{CH}_{4}-\mathrm{COD} /$ $\mathrm{gVSS} \cdot d)$. The operation of the UASB digester treating the sucrosesupplemented hydrolysed effluent was stable up to an HRT of $3.4 \mathrm{~h}$, while the UASB treating the synthetic effluent was able to 
reach a minimum HRT of $1.3 \mathrm{~h}$. In the first case, the key to digester instability would appear to be related to its ability to retain biomass and, thus, to the sedimentation characteristics of developed sludge. These results agree only partially with the findings of Singh et al. (1996), who reported granules that were larger and stronger treating synthetic effluents. Although the SS concentration in the influent was similar in both cases, there were differences between the type of SS, since the SS coming from the pre-hydrolysed domestic wastewater were in part colloidal solids. Moreover, pre-hydrolysed domestic wastewater contains other particulate and soluble substances that may influence granulation.

In conclusion, several factors may hinder the granulation process during the anaerobic treatment of diluted wastewaters with UASB digesters. The viability of granulation during the anaerobic treatment of municipal or domestic wastewater, even when prehydrolysed, is not clear and more research is needed. These future studies should focus on the factors that control the dynamic equilibrium between both granular and non-granular sludge fractions. Efficient biomass retention equipment and digester designs which contribute to this objective are also needed.

\section{Acknowledgements}

This work was part of project XUGA10307A97, supported by the "Conselleria de Educación e Ordenación Universitaria (Dirección Xeral de Universidades e Investigación)" of "Xunta de Galicia".

\section{References}

BRITO AG, RODRÍGUES AC and MELO LF (1997) Granulation during the start-up of a UASB reactor used in the treatment of low strength wastewaters. Biotechnol. Lett. 19 (4) 363-367.

ELEFSINIOTIS P and OLDHAM WK (1994) Substrate degradation patterns in acid-phase anaerobic digestion of municipal primary sludge. Environ. Technol. 15 (8) 741-751.

ELMITWALLI TA, ZANDVOORT MH, ZEEMAN G, BRUNING H and LETTINGA G (1999) Low temperature treatment of domestic sewage in upflow anaerobic sludge blanket and anaerobic hybrid reactors. Water Sci. Technol. 39 (5) 177-185.

FANG HHP, CHUI HK and LI YY (1994) Microbial structure and activity of UASB granules treating different wastewaters. Water Sci. Technol. 30 (12) 87-96.

GNANADIPHATHY A and POLPRASERT C (1993) Treatment of a domestic wastewater with UASB reactors. Water Sci. Technol. 27(1) 195-203.
HAWKES FR, DONNELLY T and ANDERSON GK (1995) Comparative performance of anaerobic digesters operating on ice-cream wastewater. Water Res. 29 (2) 525-533.

HICKEY RF, WU W, JONES R and VEIGA MC (1995) The start-up, operation, monitoring and control of high-rate anaerobic treatment systems. Water Sci. Technol. 24 (8) 207-255.

HULSHOFF POLLW (1989) The Phenomenon of Granulation of Anaerobic Sludge. Ph. D. Thesis, Wageningen Agric. Univ., The Netherlands.

LETTINGA G, DE MAN A, VAN DER LAST ARM, WIEGANT W, VAN KNIPPENBERG K, FRIJNS J and VAN BUEREN JCL (1993) Anaerobic treatment of domestic sewage and wastewaters. Water Sci. Technol. 27 (9) 67-73.

LIGERO P, VEGA A and SOTO M (2001). Pretreatment of urban wastewaters in a hydrolytic upflow digester. Water SA 27(3) 1-6.

QUARMBY J and FORSTER CF (1995) A comparative study of the internal architecture of anaerobic granular sludges. J. Chem. Tech. Biotechnol. 63(1) 60-68.

RAMOS J, OBAYA MC, VALDEZ E, VILLA P and ENG F (1994) Granulation of digested sewage sludge in mesophilic UASB reactors treating distillery waste wasters from sugar cane molasses. Acta Biotechnol. 14 (3) 281-290.

RINZEMA A (1988) Anaerobic Treatment of Wastewater with High Concentrations of Lipids or Sulphate. Ph.D. Thesis, Wageningen Agric. Univ., The Netherlands.

RUIZI, SOTO M, DE VEGA A, LIGERO P,VEIGA MC and BLÁZQUEZ $\mathrm{R}$ (1998) Performance and biomass characterization of a UASB reactor treating domestic wastewater at ambient temperature. Water SA 24 (3) 215-222.

SAYED S (1987) Anaerobic Treatment of Slaughterhouse Wastewaters Using the UASB-Process. Ph.D. Thesis, Wageningen Agric. Univ., The Netherlands.

SINGH KS, HARADA H and VIRARAGHAVAN T (1996) Low-strength wastewater treatment by a UASB reactor. Bioresour. Technol. 55 (3) 187-194.

SOTO M, LIGERO P, DE VEGA A, VEIGA MC and BLÁZQUEZ R (1997) Sludge Granulation in UASB Digesters Treating Low Strength Wastewaters at Mesophilic and Psychrophilic Temperatures. Environ. Technol. 18 (11) 1133-1141.

STANDARD METHODS (1985) Standard Methods for the Examination of Water and Wastewater (17th edn.), APHA-AWWA-WPCF, Washington.

VAN DER LAST ARM and LETTINGA G (1992) Anaerobic treatment of domestic sewage under moderate climate (dutch) conditions using upflow reactors at increased superficial velocities. Water Sci. Technol. 25 (7) 167-178.

VIEIRA SMM, CARVALHO JL, BARIJAN FP and RECH CM (1994) Application of the UASB technology for sewage treatment in a small community at Sumare, Sao Paulo State. Water Sci. Techol. 30 (12) 203-210. 
